\section{Field Performance of 'Sanna' Lingonberry Derived by Micropropagation vs. Stem Cuttings}

\author{
Björn A. Gustavsson \\ Balsgård-Department of Horticultural Plant Breeding, S-29194 Kristianstad, \\ Sweden \\ Vidmantas Stanys \\ Lithuanian Institute of Horticulture, 4335 Babtai, Kaunas District, Lithuania
}

Additional index words. Vaccinium, cowberry, mountain cranberry, tissue culture, fruiting, rhizomes

\begin{abstract}
Field performance in lingonberry (Vaccinium vitis-idaea L. cv. Sanna) was compared in 1995-97 for plants produced by tissue culture (TC) vs. stem cuttings (SC). Pot plants of about the same size were transplanted from the nursery to an infertile, sandy moraine soil. Survival was $97 \%$ for the TC plants but only $83 \%$ for the SC plants. Fruit yield was significantly greater for TC plants than for SC plants in both the second $(+79 \%)$ and third $(+190 \%)$ years, but mean fruit weight was not influenced by propagation method. Rhizome production and total plant weight were also greater for the TC plants. Although micropropagation may give rise to somaclonal variation, no obviously variant plants were apparent in the field.
\end{abstract}

Lingonberry is a small fruit species of considerable economic importance in northern Europe. Despite the fact that many fruits are still harvested from the wild, urban encroachment, changes in forest management, variable fruit quality from native stands, and fluctuations in annual yield have stimulated initiatives to domesticate and cultivate this species. Commercial cultivation was introduced in Germany during the 1980s, and more recently in the United States.

Lingonberry can be vegetatively propagated by tissue culture, stem cuttings, and rhizomes. Reproduction by rhizomes is predominant in its natural habitat. Thus, collecting rhizome-derived daughter plants is an easy and often quite successful method of propagation. When daughter plants with visible roots are placed in peat soil, they grow quickly to marketable size. However, rhizome production may be sparse in some varieties. For large-scale plant production this method is time-consuming and laborious. The resulting plants generally differ in size.

In commercial enterprises, rooting of softwood stem cuttings in peat has been the conventional method of propagation. This is generally cost effective but success rates vary among clones and years (Gustavsson, 2000).

Propagation of lingonberry plants by tissue

Received for publication 8 Mar. 1999. Accepted for publication 25 Aug. 1999. We thank Prof. H. Nybom and Prof. G. Redalen for constructive comments and review of the manuscript. This research was supported by grants from the County Administrative Board in Kalmar Iän and from the European Union Structure Funds. The cost of publishing this paper was defrayed in part by the payment of page charges. Under postal regulations, this paper therefore must be hereby marked advertisement solely to indicate this fact. culture (Gebhardt and Friedrich, 1986; Hosier et al., 1985; Riechers and Bünemann, 1989; Serres et al., 1994) is becoming increasingly common commercially, since this is a reliable and efficient method, especially for rapid introduction of new cultivars. However, micropropagation has resulted in changes, some positive, some negative, in the growth habit of several fruit crops, including blackberries $(R u$ bus nigra L.) and strawberries (Fragaria $\times$ ananassa Duchesne) (Damiano, 1980; Swartz et al., 1981, 1983). Rooted stem cuttings of lingonberry failed to produce rhizomes, from which new shoots arise (Holloway, 1985; Lehmushovi, 1975; Öster, 1976), and plants are more expensive than those of other smallfruit crops. We wished to determine to what extent improved field performance (e.g., growth, fruiting, and regeneration) of micropropagated plants is able to compensate for the higher initial costs involved.

This study compared initial field performance of lingonberry derived by stem cuttings with those obtained by tissue culture. Parameters monitored included: plant losses, winter damage, weight and fruit yield, accumulated plant growth, and number of rhizome-derived daughter plants.

\section{Materials and Methods}

Terminal stem cuttings (SC) (5-8 cm long) of 'Sanna' were collected from stock plants at Balsgård in Summer 1993 and transplanted to a propagation chamber for rooting. The cutpeat : 1 perlite under a sealed polyethylene tent (to maintain high humidity) and natural daylength. Plant material for tissue culture (TC) was collected from the same source as for SC and was grown on woody plant medium tings were rooted in flats with 4 sphagnum
(WPM) (Lloyd and McCown, 1980) containing $30 \mathrm{~g} \cdot \mathrm{L}^{-1}$ sucrose and $5 \mathrm{mg} \cdot \mathrm{L}^{-1} 2$-isopentenyl adenine ( $2 \mathrm{iP}$ ) before being rooted (in the same medium as SC plants) in the greenhouse with high humidity and artificial light (long day) in Winter 1993-94. No rooting compound was applied to either the TC or the SC plants. Wellrooted and approximately similar-sized pot plants from both propagation sources were transplanted in Fall 1994 from the nursery to an experimental field at Balsgård $\left(56^{\circ} 7^{\prime} \mathrm{N}\right.$, $\left.14^{\circ} 10^{\prime} \mathrm{E}\right)$. The soil in this field is a low-fertility, sandy moraine, $\mathrm{pH}$ 5.6. Plants were grown in one row with three blocks of 10 plants each for a total of 30 plants per propagation method, at a spacing of $40 \mathrm{~cm}$.

The field was mulched with $3-4 \mathrm{~cm}$ milled peat 1 year after planting, and broadcast fertilized each spring with $200 \mathrm{~kg} \cdot \mathrm{ha}^{-1}$ Complesal (Hoechst, Lomma, Sweden) 12N-5P-14K. Irrigation was provided only in periods with prolonged lack of precipitation. Total fruit yield and fruit weight were measured in 1996 and 1997. Data for accumulated plant growth aboveground (g/plant) and number of rhizomederived daughter plants were obtained at the end of the experiment (Fall 1997). Berries were harvested from each plant together with its rhizome-derived daughter plants. The accumulated growth was determined by destructive harvest of the whole plant (together with daughter plants) at the soil surface. The phytomass was weighed and the total number of visible daughter plants recorded. Successful field establishment was recorded after one season's growth as well as notes on visual evidence of possible somaclonal variation and identifiable winter injury.

For statistical analyses, Super Anova computer package v. 1.11 (Abacus Concepts, Berkeley, Calif.) was used.

\section{Results}

On average, $97 \%$ of the TC plants survived field establishment vs. 83\% of the SC plants. The leaves were generally larger on TC plants than on SC plants (visual comparisons only). The SC plants flowered during the first growing season after field planting, and some fruit set occurred but yield was not measured $(<1 \mathrm{~g} /$ plant). No TC plants flowered in the season after planting. In the second year after field planting, both SC and TC plants flowered, and the berries were harvested for yield estimations.

The fruit yield of TC plants was significantly greater $(P \leq 0.05)$ than that of SC plants in the second year after planting in the field (Table 1). In the third year, TC plants produced more than twice as much fruit as SC plants (46 and $22 \mathrm{~g}$, respectively, $P \leq 0.001$ ). Variation in yield was greater among TC plants than among SC plants (Table 2). Average fruit weight did not differ between the two treatments in either year (Table 1).

The TC plants produced significantly more rhizome-derived daughter plants $(P \leq 0.001)$ (Table 1). Rhizomes began to develop on the TC plants in the first season after planting, but shoots were not visible above the soil surface 
Table 1. Field performance of stem cuttings (SC), and tissue culture plants (TC), of lingonberry.

\begin{tabular}{|c|c|c|c|c|c|c|c|}
\hline \multirow[b]{2}{*}{ Source } & \multicolumn{2}{|c|}{$\begin{array}{l}\text { Fruit yield } \\
\text { (g) }\end{array}$} & \multicolumn{2}{|c|}{$\begin{array}{l}\text { Fruit wt } \\
(\mathrm{mg})\end{array}$} & \multicolumn{2}{|c|}{$\begin{array}{c}\text { Daughter plants } \\
\text { (no. per plant) }\end{array}$} & \multirow{2}{*}{$\begin{array}{c}\begin{array}{c}\text { Accumulated growth } \\
(\mathrm{g})\end{array} \\
1997\end{array}$} \\
\hline & 1996 & 1997 & 1996 & 1997 & 1996 & 1997 & \\
\hline SC plants & 4.3 & 22 & 420 & 390 & 0.0 & 0.3 & 24 \\
\hline TC plants & 7.5 & 46 & 430 & 370 & 2.4 & 7.8 & 43 \\
\hline ANOVA & $*$ & $* * *$ & NS & NS & $* * *$ & $* * *$ & $* * *$ \\
\hline
\end{tabular}

ss, ${ }^{*},{ }^{* * *}$ Nonsignificant or significant at $P \leq 0.05$ or 0.001 by ANOVA.

${ }^{z}$ Derived from rhizomes.

until the second year. In 1996, they produced an average of 2.4 daughter plants, whereas none had developed on any of the SC plants (Table 1). In 1997, they produced 7.8 daughter plants and the SC plants 0.3. Most SC plants did not produce rhizomes, while most TC plants produced between 1 and 15 daughter plants (Table 2).

The TC plants had grown more than had the SC plants $(P \leq 0.001)$ by the third year after field planting (Table 1). No visible winter damage on shoots or flower buds was noticed during the 3-year study, although Winter 1996 was rather cold and devoid of snow-cover for long periods. Also, no variant plants caused by somaclonal variation (e.g., chlorophyll deficiencies and morphological aberrations) were observed in the field.

\section{Discussion}

In our study, plants derived from tissue culture (TC) produced more rhizomes and consequently provided a larger framework for flower bud production during the experiment than did those produced by stem cuttings (SC). Field performance of micropropagated lingonberries is similar to that of highbush blueberries (V.corymbosum L.). Grout et al. (1986) reported more basal branches and lateral shoots on micropropagated plants of highbush blueberry than on those propagated by stem cuttings, and Read et al. (1988) obtained more flower buds and higher yields on micropropagated highbush cultivars. By contrast, micropropagated lowbush blueberries ( $V$. angustifolium Aiton) generally produced fewer flower buds than did conventionally propagated plants (Morrison and Smagula, 1986).

In accordance with our results with lingonberry, micropropagated strawberry plants produce more runners than conventionally propagated plants (Boxus et al., 1984), and micropropagated brambles (Rubus sp.) grow vigorously and fruit precociously and heavily (O’Dell, 1989). In apple (Malus $\times$ domestica Borkh.) (Webster et al., 1985) and cherry (Prunus avium L.) (Rosati and Gaggioli, 1987, $1989)$, the juvenile period is longer in micropropagated than in budded trees, resulting in delayed fruiting. Our TC lingonberry plants also developed flower buds and started fruiting later than SC plants, but lower initial yield appeared to be compensated for by higher yield in subsequent seasons. Because of their greater vigor, TC-derived plants can be clearly distinguished from SC plants visually after a few years in the field.

Because the cost for individual lingon- berry plants is rather high and significant returns in fruit production are delayed, plant losses must be kept to a minimum. In our study, plant loss after field transplanting was substantially lower for TC than for SC plants. Similarly plant establishment was superior for micropropagated raspberries (Rubus idaeus L.) than for conventionally propagated plants (Deng et al., 1993). In our study, some SC plants were broken off at the soil surface, presumably because most had only one stem, which could be easily damaged during transplanting or by heavy snow. New shoots seldom sprouted on such plants. By contrast, TC plants branched more and were consequently less vulnerable.

Genetic variation has frequently been observed in plants regenerated from tissue cultures (Larkin and Scowcroft, 1981). The degree and type of variation is affected by several factors, including genotype (Lee and Philips, 1988). No obviously variant 'Sanna' plants were observed in our study.

Cuttings are generally collected from the upper part of the stock plant, which is adult and gives rise to adult plants with little or no ability to produce rhizomes. Conversely, first generation cuttings from micropropagated stock plants form many (personal observation). However, we do not know how long this phase can be sustained in the stock plants, and whether daughter plants from rhizomes will retain the ability to produce new rhizomes in future generations.

This study has clearly demonstrated that TC lingonberry plants of cv. Sanna are superior to SC plants regarding fruit yield, rhizome production, and vigor (accumulated plant growth), at least for the first 3 years of field cultivation. The TC plants yield better than do SC plants because of their larger size. Plants from stem cuttings can be grown only for fruit production since they are unsuitable as stock plants for further propagation. Growers who wish to collect the rhizome-derived daughter plants for division and further propagation would benefit considerably from using TC plant material. More lingonberry genotypes need to be investigated, however, in order to determine whether TC plants are cost effective in all situations.

\section{Literature Cited}

Boxus, P., C. Damiano, and E. Brasseur. 1984 Strawberry, p. 453-0486. In: D.A. Amirato, P.V. Evans, W.R. Sharp, and Y. Yamada (eds.). Handbook of plant cell culture. Vol. 3. Crop species. Macmillan, New York.

Damiano, C. 1980. Strawberry micropropagation,
Table 2. Effects of method of propagation of lingonberry on variation in cumulative number of daughter plants produced per mother plant and total yield of fruit from both mother and daughter plants after 3 years in the field. $(n=30)$.

\begin{tabular}{lcc}
\hline \multirow{2}{*}{$\begin{array}{l}\text { Response } \\
\text { category }\end{array}$} & \multicolumn{2}{c}{ Method of propagation } \\
\cline { 2 - 3 } Tissue culture (TC) & Cuttings (SC) \\
\multicolumn{3}{c}{$\begin{array}{c}\text { No. of mother plants in each category } \\
\text { No. of daughter plants }\end{array}$} \\
\hline 0 & 3 & 24 \\
$1-5$ & 9 & 5 \\
$6-10$ & 10 & 0 \\
$11-20$ & 6 & 0 \\
$21-$ & 2 & 0 \\
SE & 1.1 & 0.2 \\
Yield (g) & & \\
\hline 0 & 2 & 6 \\
$1-19$ & 3 & 9 \\
$20-29$ & 8 & 3 \\
$40-59$ & 6 & 2 \\
$60-79$ & 5 & 0 \\
$80-99$ & 6 & 3.7 \\
SE & 5.6 & \\
\hline
\end{tabular}

p. 11-22. In: Proc. Conf. Nursery Prod. of Fruit Plants through Tissue Culture-Application and Feasibility. USDA-SEA. Agr. Res. Results ARR-NE-11.

Deng, R., D.J. Donnelly, and D.J. Buszard. 1993. Field performance of micropropagated and conventionally propagated red raspberry. Acta Hort. 336:185-191

Gebhardt, K. and M. Friedrich. 1986. In vitro shoot regeneration of lingonberry clones. Gartenbauwissenschaft 51:170-175.

Grout, J.M., P.E. Read, and D.K. Wildung. 1986. Influence of tissue culture and leaf-bud propagation on the growth habit of 'Northblue' blueberry. J. Amer. Soc. Hort. Sci. 111:372-375.

Gustavsson, B.A. 2000. Effects of collection time and environment on the rooting of lingonberry (Vaccinium vitis-idaea L.) stem cuttings. Acta Agr. Scand. (In press.)

Holloway, P.S. 1985. Rooting of lingonberry, Vaccinium vitis-idaea, stem cuttings. Plant Propagator 31:7-9.

Hosier, M.A., G. Flatebo, and P.E. Read. 1985. In vitro propagation of lingonberry. HortScience 20:364-365.

Larkin, P.J. and W.R. Scowcroft. 1981. Somaclonal variation-A novel source of variability from cell cultures for plant improvement. Theor. Appl. Genet. 60:197-214.

Lee, M. and R.L. Philips. 1988. The chromosomal basis of somaclonal variation. Annu. Rev. Plant Physiol. Plant Mol. Biol. 39:413-437.

Lehmushovi, A. 1975. Methods of propagating the cowberry. Ann. Agr. Fenn. 14:325-333.

Lloyd, G. and B. McCown. 1980. Commercially feasible micropropagation of mountain laurel, Kalmia latifolia, by use of shoot tip culture. Intl. Plant Prop. Soc. Proc. 30:421-427.

Morrison, S.E. and J.M. Smagula. 1986. Morphology, growth, and rhizome development of lowbush blueberry tissue culture plants, seedlings, and rooted softwood cuttings. HortScience 21:734.

O'Dell, C.R. 1989. Berries: Marketing raspberries. Amer. Fruit Grower 109:34-035.

Öster, H.-E. 1976. Delprojekt Vaccinium. Slutrapport till Norrlandsfonden. Dept. Fruit Prod., Swedish Univ. Agr. Sci., Alnarp.

Read, P.E., A.S. Economou, C.A. Hartley, J.M. Grout, and C.D. Fellman. 1988. A summary of stock plant influences on woody plant tissue culture success with special emphasis on the 


\section{Propagation \& Tissue Culture}

Ericaceae. Acta Hort. 227:476-478.

Riechers, U. and G. Bünemann. 1989. Mikrovermehrung von Preiselbeeren (Vaccinium vitis-idaea). Erwerbsobstbau 31:129-132.

Rosati, P. and D. Gaggioli. 1987. Field performance of micropropagated peach rootstocks and scion cultivars of sour cherry and apple. Acta Hort. 212:379-390.

Rosati, P. and D. Gaggioli. 1989. Orchard response of micropropagated sour cherry and apple cultivars. Scientia Hort. 39:201-209.

Serres, R.A., S. Pan, B.H. McCown, and E.J. Stang. 1994. Micropropagation of several lingonberry cultivars. Fruit Var. J. 48:7-14.

Swartz, H.J., G.J. Galletta, and R.H. Zimmerman. 1981. Field performance and phenotypic stability of tissue culture-propagated strawberries. J. Amer. Soc. Hort. Sci. 106:667-673.
Swartz, H.J., G.J. Galletta, and R.H. Zimmerman. 1983. Field performance and phenotypic stability of tissue culture-propagated thornless blackberries. J. Amer. Soc. Hort. Sci. 108:285290.

Webster, A.D., V.D. Oehl, J.E. Jackson, and O.P Jones. 1985. The orchard establishment, growth and precocity of four micropropagated apple scion cultivars. J. Hort. Sci. 60:169-180. 